\title{
An Economic Inquiry on Export Trend and Weekly Price Direction of Onion
}

\author{
R. Ravikumar* \\ Department of Social Science, Vanavarayar Institute of Agriculture, Pollachi-642103, India \\ *Corresponding author
}

\section{A B S T R A C T}

\section{Keywords \\ Onion, Trend, Price direction and weekly price index \\ Article Info \\ Accepted: \\ 24 July 2020 \\ Available Online: \\ 10 August 2020}

Onion is very important in cookery; hence it is called the "Queen of kitchen. The onions are regarded as a highly export oriented crop and earn valuable foreign exchange for the country. The study had made an attempt to study the export trend and domestic behavior. The study has been undertaken ontime series data framework using secondary data to find the direction of weekly prices. It can be inferred that the export quantity increased from $4.17 \%$ in period $1987-1999$ to $6.90 \%$ during period $2000-2019$. The export value also depicts a rise from $13.25 \%$ during period 1987-1999 to $14.52 \%$ during period $2000-2019$. But the unit value decreased during the period 2000-2019. From the weekly price index it was noticed that price index declines upto $20^{\text {th }}$ week and tend to increase upto $40^{\text {th }}$ week and from $41^{\text {st }}$ week price slopes to declines.

\section{Introduction}

Agriculture is the primary source of live hood for 58 percent of India's population and provides employment to 250 million of the countries workforce (Economic Survey of India, 2019). The average annual growth rate in real terms in agriculture has remained static in the last six years was 2.88 percent from 2015 to 2019. In the last decade horticulture crops in India are being cultivated in around 25 million hectares, contributes seven percent of India's total cropped area with annual production of around 295 million tonnes, which includes 175 million tonnes of vegetables and 92 million tonnes of fruits. (Agricultural Statistics -A glance, 2019).
Among the horticultural crops, Onion is one of the most important vegetable crops called the "Queen of kitchen" cultivated in varied range of climatic situations. It is an export oriented crop and earn foreign exchange for the country. India is the second largest producer of onion, accounts of one fifth percent of total global production. India is leading exporter of onion recorded 500 million dollar in the year 2019 (APEDA, 2019). Even though India take the leading position, the prices onion prices increase in the country creates looming crisis to trigger food inflation. In another period bumper harvest leads to market glut situation and brings down the onion prices and crashes the producers. In this galloping price rise in onion 
background, an attempt was made to understand weekly price signals help to promote onion arrivals on need time to match the demand supply pattern. With the research background research was made to study export trend and domestic behavior with the following objectives. The specific objectives are i) to analyze trend and instability of onion export ii) To examine the direction of weekly price direction of Onion in India iii) to study yearly peak, normal and lean price of onion The hypothesis of the study (H0) no difference in growth and instability in export quantity and (H1) difference in growth and instability in export quantity to analyze trend and instability. Also hypothesized (Ho) there is no direction of price between weeks and (H1) direction of price between weeks.

\section{Materials and Methods}

The study has been undertaken on time series data context using secondary data collected from authorized websites. Onion exports data has collected from APEDA and onion weekly prices had collected from major onion market as reference market for onion.

\begin{tabular}{|l|l|l|l|}
\hline Particulars & $\begin{array}{l}\text { Data collection } \\
\text { period }\end{array}$ & Source & $\begin{array}{l}\text { Number of } \\
\text { Observations }\end{array}$ \\
\hline $\begin{array}{l}\text { Yearly Export } \\
\text { Quantity }\end{array}$ & 1985 to 2019 & APEDA & 408 \\
\hline Weekly onion price & 2010 to 2019 & AGMARK & 520 \\
\hline
\end{tabular}

Compound growth rate analysis, Coppock's instability index and Season Index tools are used analyses the data. The details description of data is furnished below.

\section{Compound growth rate}

Compound Growth rate was used to examine the trend in export quantity, export value and unit price of onion. Exponential growth model was selected for the analysis and the model is of following form

$$
\mathrm{Y}=\mathrm{ab}{ }^{\mathrm{t}} \mathrm{e}_{\mathrm{t}}
$$

Where, $\mathrm{Y}=$ Dependent variable for which growth rate is estimated $\mathrm{a}=$ Interceptb $=$ Regression coefficient, $\mathrm{t}=$ Time variablee $=$ error term

The logarithmic form of compound growth rate used $=\ln Y=\ln a+t \ln b$

Where, $\ln \mathrm{Y}$ is natural logarithm of $\mathrm{Y}, \mathrm{Ln}$ a andln $b$ are similarly defined.
The compound growth rate ' $r$ ' was computed by using the relationship

$$
r=(\text { Antilog of }(\operatorname{lnb}) \times 100)
$$

where, $\ln \mathrm{b}=\quad \underline{\Sigma(\mathrm{t} \ln \mathrm{Y})-(\Sigma \mathrm{t} \Sigma \ln \mathrm{Y}) / \mathrm{n}}$

$$
\Sigma\left(\mathrm{t}^{2}\right)-\left(\Sigma \mathrm{t}^{2}\right) / \mathrm{n}
$$

The significance of $\ln b$ was tested by t-ratio.

$$
t=\frac{|\ln b|}{S E(\ln b)()}
$$

Where $\mathrm{SE}(\ln \mathrm{b})=\left(\mathrm{SS}_{\ln \mathrm{Y}}\left(\ln \mathrm{Y}^{2}\right) \mathrm{SS}_{\mathrm{t}}\right) /((\mathrm{n}-2)$ $\mathrm{SS}_{\mathrm{t}}$ )

Where, $\mathrm{SS}_{\ln \mathrm{Y}=} \Sigma\left(\ln \mathrm{Y}^{2}\right)-(\Sigma \ln \mathrm{Y})^{2} / \mathrm{n}$

\section{Coppock's instability index}

Instability in export is expected to indicate of consistency level. Coppock's instability index was used to estimate the variation and stability in Indian mango exports which was algebraically expressed as the following estimable form 


$$
\mathrm{V}=\underset{\mathrm{N}-1}{\ldots \ldots \log }\left\{\begin{array}{c}
\mathrm{X}_{\mathrm{t}+1}^{2} \\
-----\mathrm{m} \\
\mathrm{X}_{\mathrm{t}}
\end{array}\right\}
$$

The instability index was $=(\operatorname{antilog} \sqrt{ } \mathrm{V}-1) \mathrm{x}$ 100 Where,

$X_{t}=$ Value or volume/value of exports in year, $X_{t-1}$ Lag value ' $t$ ' $n=$ Number of years

\section{Seasonal index}

Seasonal index is an average that can be used to compare an actual observation relative to weekly average of various years. It depict the particular period tends to be above the average value.

Seasonal Index $=\frac{\text { Weekly Average of } 2010 \text { to } 2019}{\text { Yearly Average of } 2010 \text { to2019 }} * 100$

\section{Results and Discussion}

The results of the trend in exports quantity, export value and export unit price of onion from India for the past decades.
Trend Analysis of onion export quantity, export value and unit price of Onion

To study the export performance of onion from 1987-88 to 2016-2019, an analysis was done. For the analysis, the entire period was divided into period I (from 1987-88 to 199900), period II (from 2000-01 to 2018-19) besides overall analysis to understand the difference for the specified period.

From the table 1 it can be inferred that the export quantity increased from $4.17 \%$ in period I to $6.90 \%$ during period II. The export value also saw a rise from $13.25 \%$ during period I to $14.52 \%$ during period II.

But the unit value decreased during the period II. The increase in export is attributed to increase in production, low price and good quality compared to other onion producing countries. The unit value decreased due to increased supply of onion.

Table.1 Performance of in Export Quantity, Total Value and Unit Value of onion

\begin{tabular}{|l|c|c|c|}
\hline \multicolumn{1}{|c|}{ Year } & $\begin{array}{c}\text { Export Quantity } \\
\text { (Percentage) }\end{array}$ & $\begin{array}{c}\text { Export Value } \\
\text { (Percentage) }\end{array}$ & $\begin{array}{c}\text { Unit Value } \\
\text { (Percentage) }\end{array}$ \\
\hline Period I (1987-88 to 1999-00) & $4.17 * *$ & $13.25 * * *$ & $8.72 * * *$ \\
\hline Period II (2001 to 2018-19) & $6.90 * * *$ & $14.52 * * *$ & $-36.75 * * *$ \\
\hline Overall period & $5.12 * * *$ & $14.78 * * *$ & $-38.19 * * *$ \\
\hline
\end{tabular}

*** Significant at one per cent level. **Significant at 5 per cent level

Table.2 Results of Instability in Export Quantity, Total Value and Unit Value of Onion

\begin{tabular}{|l|c|c|c|}
\hline \multicolumn{1}{|c|}{ Year } & Export Quantity & Export Value & Unit Value \\
\hline Period I (1987-88 to 1999-00) & 30.43 & 43.57 & 33.09 \\
\hline Period II (2001 to 2018-19) & 36.61 & 61.33 & 42.00 \\
\hline Overall period & 67.39 & 104.19 & 57.73 \\
\hline
\end{tabular}


Table.3 Results of direction of weekly price index of Onion

\begin{tabular}{|c|c|c|c|c|c|c|c|c|c|c|}
\hline Week No. & 2010 & 2011 & 2012 & 2013 & 2014 & 2015 & 2016 & 2017 & 2018 & 2019 \\
\hline 1 & 122.7 & 176.2 & 244.5 & 90.8 & 158.4 & 174.4 & 239.3 & 106.3 & 136.9 & 67.6 \\
\hline 2 & 116.4 & 167.2 & 232.0 & 86.2 & 116.3 & 135.0 & 227.0 & 100.9 & 129.9 & 64.2 \\
\hline 3 & 113.6 & 163.1 & 226.3 & 84.1 & 119.0 & 141.6 & 221.4 & 98.4 & 126.7 & 62.6 \\
\hline 4 & 107.1 & 153.8 & 213.4 & 79.3 & 91.3 & 115.2 & 208.8 & 92.8 & 119.5 & 59.0 \\
\hline 5 & 95.8 & 137.6 & 190.9 & 70.9 & 84.2 & 118.7 & 186.8 & 83.0 & 106.9 & 52.8 \\
\hline 6 & 92.2 & 132.4 & 183.7 & 68.3 & 91.7 & 134.4 & 179.8 & 79.9 & 102.9 & 50.8 \\
\hline 7 & 88.8 & 127.5 & 176.9 & 65.7 & 111.9 & 170.3 & 173.1 & 76.9 & 99.0 & 48.9 \\
\hline 8 & 81.7 & 117.3 & 162.8 & 60.5 & 112.4 & 185.8 & 159.3 & 70.8 & 91.2 & 45.0 \\
\hline 9 & 65.9 & 94.6 & 131.3 & 48.8 & 98.4 & 201.7 & 128.5 & 57.1 & 73.5 & 36.3 \\
\hline 10 & 63.6 & 91.3 & 126.7 & 47.1 & 99.7 & 211.8 & 124.0 & 55.1 & 71.0 & 35.1 \\
\hline 11 & 62.6 & 89.8 & 124.7 & 46.3 & 90.5 & 195.4 & 122.0 & 54.2 & 69.8 & 34.5 \\
\hline 12 & 61.2 & 87.9 & 121.9 & 45.3 & 85.9 & 189.7 & 119.3 & 53.0 & 68.3 & 33.7 \\
\hline 13 & 63.1 & 90.6 & 125.6 & 46.7 & 91.5 & 196.1 & 123.0 & 54.6 & 70.4 & 34.8 \\
\hline 14 & 60.0 & 86.1 & 119.5 & 44.4 & 95.0 & 214.0 & 117.0 & 52.0 & 66.9 & 33.1 \\
\hline 15 & 57.9 & 83.2 & 115.5 & 42.9 & 101.5 & 236.6 & 113.0 & 50.2 & 64.6 & 31.9 \\
\hline 16 & 56.1 & 80.5 & 111.7 & 41.5 & 82.0 & 197.4 & 109.4 & 48.6 & 62.6 & 30.9 \\
\hline 17 & 54.4 & 78.2 & 108.4 & 40.3 & 64.4 & 160.0 & 106.1 & 47.1 & 60.7 & 30.0 \\
\hline 18 & 50.9 & 73.2 & 101.5 & 37.7 & 56.6 & 150.0 & 99.4 & 44.1 & 56.8 & 28.1 \\
\hline 19 & 51.2 & 73.5 & 102.0 & 37.9 & 50.9 & 134.3 & 99.8 & 44.3 & 57.1 & 28.2 \\
\hline 20 & 56.1 & 80.6 & 111.9 & 41.6 & 47.8 & 115.1 & 109.5 & 48.6 & 62.6 & 30.9 \\
\hline 21 & 66.0 & 94.7 & 131.4 & 48.8 & 39.8 & 81.4 & 128.6 & 57.1 & 73.6 & 36.4 \\
\hline 22 & 65.8 & 94.4 & 131.0 & 48.7 & 41.5 & 85.3 & 128.2 & 57.0 & 73.4 & 36.2 \\
\hline 23 & 67.9 & 97.6 & 135.4 & 50.3 & 31.5 & 62.6 & 132.5 & 58.8 & 75.8 & 37.4 \\
\hline 24 & 69.1 & 99.2 & 137.7 & 51.1 & 28.8 & 56.4 & 134.7 & 59.9 & 77.1 & 38.1 \\
\hline 25 & 74.5 & 106.9 & 148.4 & 55.1 & 29.1 & 52.7 & 145.2 & 64.5 & 83.1 & 41.0 \\
\hline 26 & 82.3 & 118.2 & 164.0 & 60.9 & 31.3 & 51.4 & 160.5 & 71.3 & 91.8 & 45.4 \\
\hline 27 & 88.3 & 126.9 & 176.0 & 65.4 & 24.5 & 37.4 & 172.3 & 76.5 & 98.5 & 48.7 \\
\hline 28 & 90.4 & 129.9 & 180.2 & 66.9 & 22.3 & 33.3 & 176.4 & 78.3 & 100.9 & 49.8 \\
\hline 29 & 103.0 & 147.9 & 205.2 & 76.2 & 26.6 & 34.9 & 200.9 & 89.2 & 114.9 & 56.8 \\
\hline 30 & 106.9 & 153.6 & 213.1 & 79.2 & 46.5 & 58.8 & 208.6 & 92.6 & 119.3 & 58.9 \\
\hline 31 & 112.5 & 161.5 & 224.1 & 83.3 & 57.0 & 68.4 & 219.4 & 97.5 & 125.5 & 62.0 \\
\hline 32 & 108.4 & 155.7 & 216.0 & 80.2 & 49.9 & 62.1 & 211.4 & 93.9 & 120.9 & 59.7 \\
\hline 33 & 108.5 & 155.9 & 216.3 & 80.3 & 59.5 & 74.1 & 211.7 & 94.0 & 121.1 & 59.8 \\
\hline 34 & 106.9 & 153.5 & 212.9 & 79.1 & 64.5 & 81.6 & 208.4 & 92.6 & 119.2 & 58.9 \\
\hline 35 & 120.0 & 172.4 & 239.2 & 88.9 & 106.4 & 119.7 & 234.1 & 104.0 & 133.9 & 66.2 \\
\hline 36 & 121.2 & 174.0 & 241.5 & 89.7 & 123.3 & 137.4 & 236.3 & 105.0 & 135.2 & 66.8 \\
\hline 37 & 128.3 & 184.2 & 255.6 & 94.9 & 131.8 & 138.8 & 250.1 & 111.1 & 143.1 & 70.7 \\
\hline 38 & 140.1 & 201.2 & 279.2 & 103.7 & 138.1 & 133.1 & 273.3 & 121.4 & 156.3 & 77.2 \\
\hline 39 & 142.6 & 204.8 & 284.2 & 105.6 & 122.6 & 116.1 & 278.1 & 123.6 & 159.1 & 78.6 \\
\hline 40 & 149.8 & 215.1 & 298.4 & 110.8 & 123.6 & 111.5 & 292.0 & 129.7 & 167.1 & 82.5 \\
\hline
\end{tabular}




\begin{tabular}{|l|l|l|l|l|l|l|l|l|l|l|}
\hline $\mathbf{4 1}$ & 154.1 & 221.3 & 307.1 & 114.1 & 120.0 & 105.2 & 300.6 & 133.5 & 171.9 & 84.9 \\
\hline $\mathbf{4 2}$ & 146.9 & 211.0 & 292.8 & 108.8 & 92.6 & 85.1 & 286.5 & 127.3 & 163.9 & 81.0 \\
\hline $\mathbf{4 3}$ & 154.5 & 221.8 & 307.8 & 114.3 & 90.2 & 78.9 & 301.2 & 133.8 & 172.3 & 85.1 \\
\hline $\mathbf{4 4}$ & 165.6 & 237.8 & 330.0 & 122.6 & 104.1 & 84.9 & 323.0 & 143.5 & 184.8 & 91.3 \\
\hline $\mathbf{4 5}$ & 168.9 & 242.5 & 336.5 & 125.0 & 102.8 & 82.2 & 329.3 & 146.3 & 188.4 & 93.1 \\
\hline $\mathbf{4 6}$ & 161.0 & 231.2 & 320.8 & 119.2 & 92.9 & 77.9 & 313.9 & 139.5 & 179.6 & 88.7 \\
\hline $\mathbf{4 7}$ & 162.6 & 233.5 & 324.0 & 120.4 & 85.4 & 71.0 & 317.1 & 140.9 & 181.4 & 89.6 \\
\hline $\mathbf{4 8}$ & 157.3 & 225.9 & 313.5 & 116.5 & 67.2 & 57.7 & 306.8 & 136.3 & 175.5 & 86.7 \\
\hline $\mathbf{4 9}$ & 159.4 & 228.9 & 317.6 & 118.0 & 73.6 & 62.4 & 310.9 & 138.1 & 177.8 & 87.9 \\
\hline $\mathbf{5 0}$ & 155.0 & 222.6 & 308.8 & 114.7 & 80.8 & 70.4 & 302.2 & 134.3 & 172.9 & 85.4 \\
\hline $\mathbf{5 1}$ & 149.2 & 214.3 & 297.3 & 110.4 & 99.1 & 89.7 & 291.0 & 129.3 & 166.5 & 82.2 \\
\hline $\mathbf{5 2}$ & 145.7 & 209.3 & 290.4 & 107.9 & 94.8 & 87.9 & 284.2 & 126.2 & 162.6 & 80.3 \\
\hline
\end{tabular}

Table.4 Summary of Year wise peak, normal and lean price week

\begin{tabular}{|c|c|c|c|c|}
\hline Year & $\begin{array}{l}\text { High Peak price weeks } \\
\text { (150 and above) }\end{array}$ & $\begin{array}{l}\text { Peak Price Weeks } \\
(120-149)\end{array}$ & $\begin{array}{c}\text { Normal Price } \\
\text { Weeks (91 to 119) }\end{array}$ & $\begin{array}{l}\text { Lean Price Weeks } \\
\text { (Below 90) }\end{array}$ \\
\hline 2010 & $41^{\text {st }}$ to $50^{\text {th }}$ Week & $\begin{array}{c}1^{\text {st }} \text { to } 3^{\text {rd }} \text { Week } \\
35^{\text {th }} \text { to } 42^{\text {nd }} \text { Week } \\
51^{\text {st }} \text { to } 52^{\text {nd }} \text { Week }\end{array}$ & $\begin{array}{l}4^{\text {th }} \text { to } 6^{\text {th }} \text { Week } \\
28^{\text {th }} \text { to } 34^{\text {th }} \text { Week }\end{array}$ & $7^{\text {th }}$ to $27^{\text {th }}$ Week \\
\hline 2011 & $\begin{array}{c}1^{\text {st }} \text { to } 4^{\text {th }} \text { Week } \\
30^{\text {th }} \text { to } 52^{\text {nd }} \text { Week }\end{array}$ & $\begin{array}{c}5^{\text {th }} \text { to } 8^{\text {th }} \text { week } \\
27^{\text {th }} \text { to } 29^{\text {th }} \text { week }\end{array}$ & $\begin{array}{l}8^{\text {th }} \text { to } 10^{\text {th }} \text { week } 21^{\text {st }} \\
\text { to } 26^{\text {th }} \text { week }\end{array}$ & $11^{\text {th }}$ to $17^{\text {th }}$ Week \\
\hline 2012 & $\begin{array}{c}1^{\text {st }} \text { to } 13^{\text {th }} \text { Week } \\
24^{\text {th }} \text { to } 50^{\text {th }} \text { Week }\end{array}$ & $\begin{array}{c}9^{\text {th }} \text { to } 13^{\text {th }} \text { week } \\
21^{\text {th }} \text { to } 23^{\text {th }} \text { week }\end{array}$ & $14^{\text {th }}$ to $20^{\text {th }}$ week & - \\
\hline 2013 & - & $44^{\text {th }}$ to $47^{\text {th }}$ week & $\begin{array}{c}1^{\text {st }} \text { week } \\
37^{\text {th }} \text { to } 42^{\text {nd }} \text { week } \\
51^{\text {st }} \text { to } 52^{\text {nd }} \text { week }\end{array}$ & $2^{\text {nd }}$ to $36^{\text {th }}$ week \\
\hline 2014 & $1^{\text {st }}$ week & $36^{\text {th }}$ to $40^{\text {th }}$ week & $\begin{array}{l}2^{\text {nd }} \text { to } 3^{\text {rd }} \text { week } \\
6^{\text {th }} \text { to } 10^{\text {th }} \text { week } 14^{\text {th }} \\
\text { to } 15^{\text {th }} \text { week } 41^{\text {st }} \text { to } \\
46^{\text {th }} \text { week } 51^{\text {st }} \text { to } \\
52^{\text {nd }} \text { week }\end{array}$ & $\begin{array}{c}11^{\text {st }} \text { to } 12^{\text {th }} \text { week } 16^{\text {th }} \\
\text { to } 34^{\text {th }} \text { week } 47^{\text {th }} \text { to } \\
50^{\text {th }} \text { week }\end{array}$ \\
\hline 2015 & $\begin{array}{c}1^{\text {st }} \text { week, } 7^{\text {th }} \text { week } \\
8^{\text {th }} \text { to } 16^{\text {th }} \text { week }\end{array}$ & $\begin{array}{c}2^{\text {nd }} \text { to } 3^{\text {rd }} \text { week } \\
6^{\text {th }} \text { week, } 19^{\text {th }} \text { week } \\
36^{\text {th }} \text { to } 38^{\text {th }} \text { week }\end{array}$ & $\begin{array}{c}4^{\text {th }} \text { to } 5^{\text {th }} \text { week } \\
35^{\text {th }} \text { to } 41^{\text {st }} \text { week }\end{array}$ & $\begin{array}{l}22^{\text {nd }} \text { to } 34^{\text {th }} \text { week } \\
42^{\text {nd }} \text { to } 52^{\text {nd }} \text { week }\end{array}$ \\
\hline 2016 & $\begin{array}{l}1^{\text {st }} \text { week, } 8^{\text {th }} \text { week } \\
26^{\text {th }} \text { to } 52^{\text {nd }} \text { week }\end{array}$ & $\begin{array}{l}9^{\text {th }} \text { to } 11^{\text {th }} \text { week, } \\
13^{\text {th }} \text { week, } \\
21^{\text {st }} \text { to } 25^{\text {th }} \text { week }\end{array}$ & $12^{\text {th }}$ to $20^{\text {th }}$ week & - \\
\hline 2017 & - & $38^{\text {th }}$ to $52^{\text {nd }}$ week & $\begin{array}{l}1^{\text {st }} \text { to } 4^{\text {th }} \text { week } \\
30^{\text {th }} \text { to } 37^{\text {th }} \text { week }\end{array}$ & $\begin{array}{c}5^{\text {th }} \text { to } 29^{\text {th }} \text { week } \\
35^{\text {th }} \text { to } 41^{\text {st }} \text { week }\end{array}$ \\
\hline 2018 & $38^{\text {th }}$ to $52^{\text {nd }}$ week & $\begin{array}{l}1^{\text {st }} \text { to } 31^{\text {th }} \text { week } \\
31^{\text {th }} \text { to } 37^{\text {th }} \text { week }\end{array}$ & $\begin{array}{c}4^{\text {th }} \text { to } 8^{\text {th }} \text { week } \\
26^{\text {th }} \text { to } 34^{\text {th }} \text { week }\end{array}$ & $9^{\text {th }}$ to $25^{\text {th }}$ week \\
\hline 2019 & $38^{\text {th }}$ to $52^{\text {nd }}$ week & $1^{\text {st }}$ to $4^{\text {th }}$ week & $26^{\text {th }}$ to $38^{\text {th }}$ week & $5^{\text {th }}$ to $25^{\text {th }}$ week \\
\hline $\begin{array}{l}\text { Frequency } \\
\text { Weeks }\end{array}$ & $1,2,3,9-47$ week & $\begin{array}{c}4,5,48,49,50,52 \\
\text { week }\end{array}$ & $\begin{array}{c}6,7,8,11-21 \\
\text { week }\end{array}$ & $\begin{array}{c}1,2,3,9-47 \\
\text { week }\end{array}$ \\
\hline
\end{tabular}


Fig.1 Result of direction of weekly price index of onion

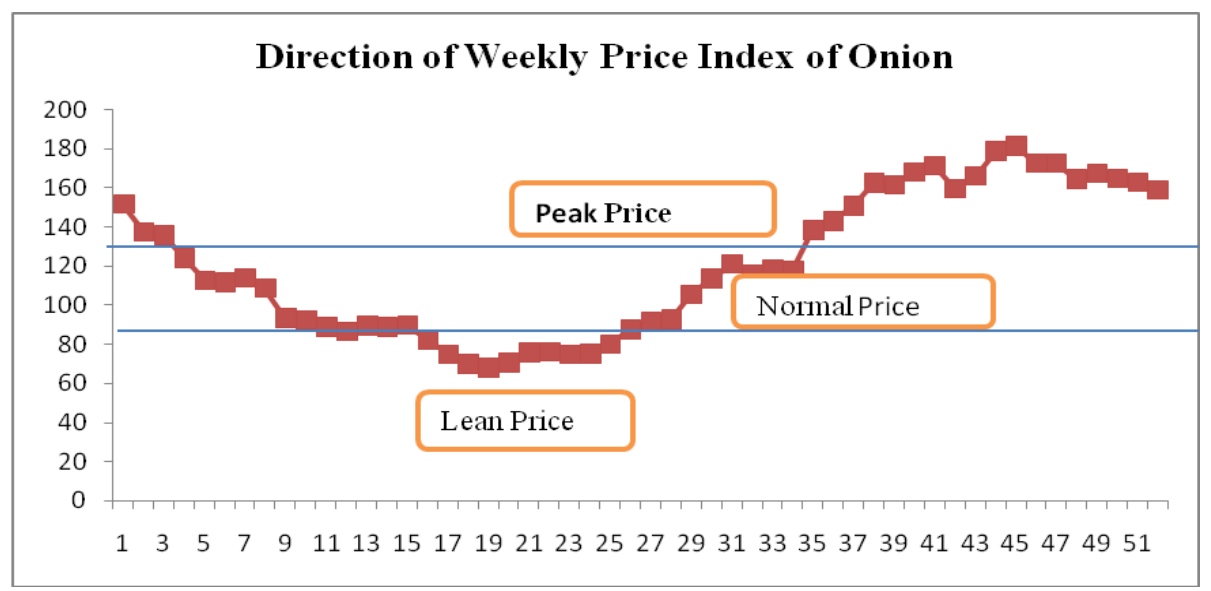

\section{Coppock's instability analysis of onion}

The Coppock's instability index was worked out for onion trade in India for the two periods to analyze the amount of instability. It is observed from Table 2 that the fluctuations in the export of onion were marginally high (36.61) during period II (2001-2016), whereas during period I (1987-00) there was less instability (30.43). The instability in the total value of onion export was marginally high during period II (61.33), compared to period I (43.57). The unit value showed a lower instability (33.09) during the period I, but the unit value became highly instable (42.00) during the period II.

In the case of onion, the fluctuations in the export of onion was high (36.61) during period II (2001 to 2019), whereas during period I (1987 to 2000) there was less instability (30.43). This indicates that export growth during period I did not fluctuate much due to less restriction and growing demand onion in the global market. The instability in the total value of onion export was high during period II (61.33), compared to period I (43.57). The unit value showed a lower instability during the period I. It showed high instability during the period II.

\section{Direction of weekly price index of onion}

Onion is one of the price volatility crop and occurrence of price change week to week. The weekly price index helps to assess the direction of prices and with arrivals in the market. The weekly price index of onion was depicted in the table 3 .

From the figure 1 the price index decreases from first week to $21^{\text {st }}$ week that was price move from peak to lean state. From $22^{\text {nd }}$ week the price index increases upto $45^{\text {th }}$ week that toward lean to peak price and tend to decline.

The weekly price index of onion was studied for the years 2010 to 2019 It was inferred from the table 4 that repeatedly peak price existed during the $1^{\text {st }}, 2^{\text {nd }}, 3^{\text {rd }}, 9^{\text {th }}$ to $47^{\text {th }}$ weeks, moderate price during $4^{\text {th }}, 5^{\text {th }}$, $48^{\text {th }}, 49^{\text {th }}, 50^{\text {th }}$ and $52^{\text {nd }}$ weeks and lean price during $6^{\text {th }}, 7^{\text {th }}, 8^{\text {th }}, 11^{\text {th }}$ to $21^{\text {st }}$ weeks.

In conclusion the export trend positive growth was observed for both the time periods Export is almost stable for both the periods. Domestic onion price changes week by week and implied that supply of onion from both production and stock. From the yearly week price index it was noted that frequency of repetition is less in all the high peak price 
weeks, Peak Price Weeks Normal Price and Lean Price Weeks

\section{Acknowledgement}

I am grateful in acknowledging the insightful guidance of Director, Principal of Vanavarayar Institute of Agriculture, Pollachi.

\section{References}

Agricultural Statistics at a Glance, 2019, Government of India Ministry of Agriculture \& Farmers Welfare Department of Agriculture, Cooperation \& Farmers Welfare Directorate of Economics and Statistics. Angles, S., Sundar, A. and Chinnadurai, M.
(2011).Impact of globalization on production and export of turmeric in India - An economic analysis. Agric. Econ. Res. Rev., 24(2): 301-308

Chandrashekhar, 2007. Analysis of onion production and marketing behaviour of farmers in Gadag district, Karnataka. M.Sc.(Agri.) Thesis, Univ. Agric Sci., Dharwad, Karnataka, India

Promod Kumar, Alkasingh, P.S. Badal, (2006) Performance of onion export from India: A temporal analysis Foreign trade review Volume: 40 issue: 4, page(s): 49-63.

Economic Survey of India 2019 Economic Division, Department of Economic Affairs, Ministry of Finance Government of India.

\section{How to cite this article:}

Ravikumar, R. 2020. An Economic Inquiry on Export Trend and Weekly Price Direction of Onion. Int.J.Curr.Microbiol.App.Sci. 9(08): 3085-3091.

doi: https://doi.org/10.20546/ijcmas.2020.908.349 